\title{
SIMULTANEOUS ESTIMATION OF RATES OF THYROXINE DEGRADATION AND THYROID HORMONE SYNTHESIS ${ }^{1}$
}

\author{
BY SIDNEY H. INGBAR 2 AND NORBERT FREINKEL 3 \\ (From the Thorndike Memorial Laboratory, Second and Fourth Medical Services (Harvard), \\ Boston City Hospital, and the Department of Medicine, Harvard Medical School, \\ Boston, Mass.)
}

(Submitted for publication December 27, 1954; accepted February 23, 1955)

Implicit in many studies of thyroidal function is the assumption that the rates of synthesis and degradation of thyroid hormone are equal (1-4). Yet this assumption has not been critically examined. Constancy of concentrations of serum precipitable iodine (SPI), particularly under conditions of environmental stress, need not indicate an equilibrium of this type, for interposed between the site of hormonal synthesis and the peripheral circulation is a large pool of stored hormone (1, 4-6). This pool is capable of maintaining, at least for a time, constancy of SPI, despite marked discrepancies between rates of hormonal production and degradation (7).

A method has been devised for simultaneous estimation of the rate of degradation of thyroxine within the body and the rate of iodination of organic moieties within the thyroid gland." The equivalence of these two functions has been assessed in patients with diverse thyroidal states. In addition, the method has been applied to an evaluation of several factors which influence the degradation of thyroxine.

\section{MATERIAL AND ANALYTIC METHODS}

The group studied included nine euthyroid individuals, five patients with untreated myxedema, nine with treated

1 This investigation was supported in part by research grant No. A-267 from the National Institute of Arthritis and Metabolic Diseases of the National Institutes of Health, Public Health Service and in part by the Medical Research and Development Board, Office of the Surgeon General, Department of the Army, under Contract No. DA-49-007-MD-412.

2 Howard R. Hughes Fellow in Medicine.

${ }^{3}$ Fellow of the American Cancer Society, Inc., recommended by the Committee on Growth of the National Research Council.

4 In the ensuing discussion, iodinated organic moieties stored within the thyroid gland, regardless of their specific chemical nature, will be termed "thyroid hormone." myxedema, five with Graves' disease, and three with panhypopituitarism. Diagnoses were established on the basis of clinical picture, determination of BMR, thyroidal uptake of $I^{m 2}$, SPI, and when necessary, measurements of adrenal and pituitary gonadotrophic function. All patients were studied on a metabolic ward, receiving constant weighed diets ranging from 2,000 to 4,000 in caloric content.

Each patient received from 3 to $5 \mu \mathrm{g}$. of 1-thyroxine intravenously, labelled with 30 to $50 \mu \mathrm{C}$ of $I^{\mathrm{mm}}$. At 24hour intervals the thyroidal content of radioiodine was measured with a directional scintillation counter (sodium iodide crystal, thallium activated) positioned 20 on from the neck. Radioactivity over the midthigh was subtracted from that observed over the neck in order to "correct" for extrathyroidal radioactivity. Samples of serum and 24-hour collections of urine were obtained daily in carefully cleaned glassware. In patients with thyrotoxicosis, samples of serum were obtained twice daily. In patients in whom fecal collections were made, powdered carmine was used as a marker. Weighed aliquots of homogenized stool were prepared. Radioactivity in all samples of serum, urine, and feces was determined in a well-type scintillation counter (sodium iodide crystal, thallium activated), and in all instances was expressed as a percentage of the administered dose. Corrections for physical decay were obviated by comparing the activity of all samples to that of a suitably diluted fraction of the administered dose. Sufficient counts were observed to reduce the probable error of results to less than one per cent. Analyses for stable iodine were performed by the method of Barker, Humphrey, and Soley in serum (8) and the method of Barker in urine (9).6 Statistical analyses were performed according to methods described by Snedecor (10).

\section{METHOD OF ANALYSIS}

Following the intravenous administration of radioactive thyroxine $\left(T x^{*}\right)$, the virtual volume of distribution of injected material was calculated daily according to the principle employed by Myant and Pochin and by Benua, Albert, and Keating in the study of the distribution of radiothyroxine in man $(11,12)$.

Thus, where,

- Obtained from Abbott Laboratories, Chicago, Ill.

- Performed by Bioscience Laboratories, 2231 Carmelina Avenue, Los Angeles 64, Calif. 
TDS = The "thyroxine distribution space" or volume of distribution of thyroxine at any time, $t$ (liters).

$\mathrm{R}=$ Residual radiothyroxine (Per cent of the administered radiothyroxine remaining within the thyroxine space at any time, $t$. Total dose minus sum of thyroidal, fecal and urinary collections of $I^{m+1}$ up to time, $t$ ).

$\mathbf{P}=$ Concentration of $T x^{*}$ in plasma at time, $t$ (per cent dose per liter).

$$
\mathbf{T D S}=\mathbf{R} / \mathbf{P} \text {. }
$$

Mixing of $\mathrm{Tx}^{*}$ was assumed to be complete when calculated values of TDS became constant. The subsequent slope of the exponential curve depicting the concentration of $\mathrm{Tx}^{*}$ in the plasma was considered to represent solely the metabolism of labelled hormone. The time required for the concentration of isotope to decrease by 50 per cent (half-time, $t 1 / 2$ ) was determined by inspection of the metabolic slope, and the fractional rate of turnover of thyroxine (k) was calculated according to the formula,

$$
\text { k }(\text { proportion } / \text { day })=0.693 / t^{1} / 2 \text { (days). }
$$

In addition, where

$\mathrm{V}=$ Daily volume turnover or the volume of the TDS whose hormone is replaced daily (liters per day).

ETT = Extrathyroidal thyroxine. Thyroxine contained within the TDS ( $\mu \mathrm{g}$. thyroxine I).
SPI = Serum precipitable iodine ( $\mu \mathrm{g}$. I per $100 \mathrm{ml}$.$) .$ $D=$ Thyroxine degradation rate ( $\mu$ g. thyroxine I per day).

$$
\begin{aligned}
& \mathrm{V}=\mathrm{TDS} \times \mathrm{k} \\
& \mathrm{ETT}=\mathrm{TDS} \times \mathrm{SPI} \times 10 \\
& \mathrm{D}=\mathrm{V} \times \mathrm{SPI} \times 10 .
\end{aligned}
$$

During the degradation of radioactive thyroxine, radioiodine accumulates in three sites: the thyroid, urine, and feces (Figure 1). That within the urine and thyroid has been demonstrated to arise principally from inorganic $I^{m}$ liberated by the peripheral degradation of thyroid hormone (11-13). Fecal radioactivity has been shown to be largely organic (13). The plasma's radioactivity was considered to consist entirely of $T x^{*}$. However, since inorganic radioiodine must certainly have entered thyroid and urine from the plasma, a fraction of the plasma's radioiodine must at all times have been inorganic. Previous authors have considered this fraction to be negligibly small (11-13). One estimate of the magnitude of this inorganic moiety could be derived by substituting in the conventional clearance formula the daily excretion of radioiodide and an assumed daily renal iodide clearance of 48 liters (11). Inorganic radioactivity in plasma was found by this technique to contribute no more than 1 to 2 per cent to the total radioactivity of plasma. Furthermore, in 11 patients, 93 to 99

\section{SCHEMA OF THE DISTRIBUTION \& FATE OF A SINGLE DOSE OF THYROXINE - I ${ }^{131}$ DISPLAYING DELAYED MIXING}

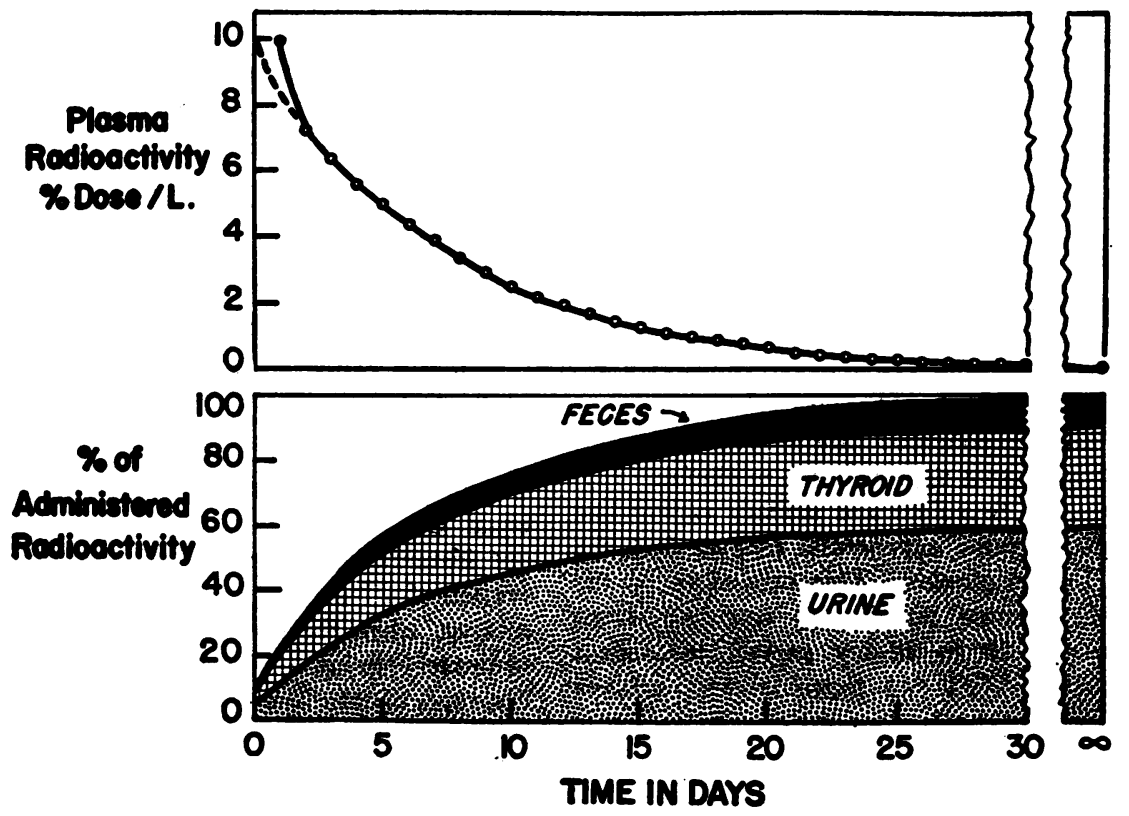

Fig. 1. Fate of a Single Intravenous Dose of Radioactive Thyroxine

Fecal, urinary, and thyroidal accumulation of $\mathrm{I}^{\mathrm{Im}}$ approach their maximum at the same exponential rate at which the concentration of radiothyroxine in plasma approaches a minimum. Metabolism of radiothyroxine prior to completion of mixing results in an early rapid accumulation of $\mathrm{I}^{20}$ in urine, thyroid, and feces. 

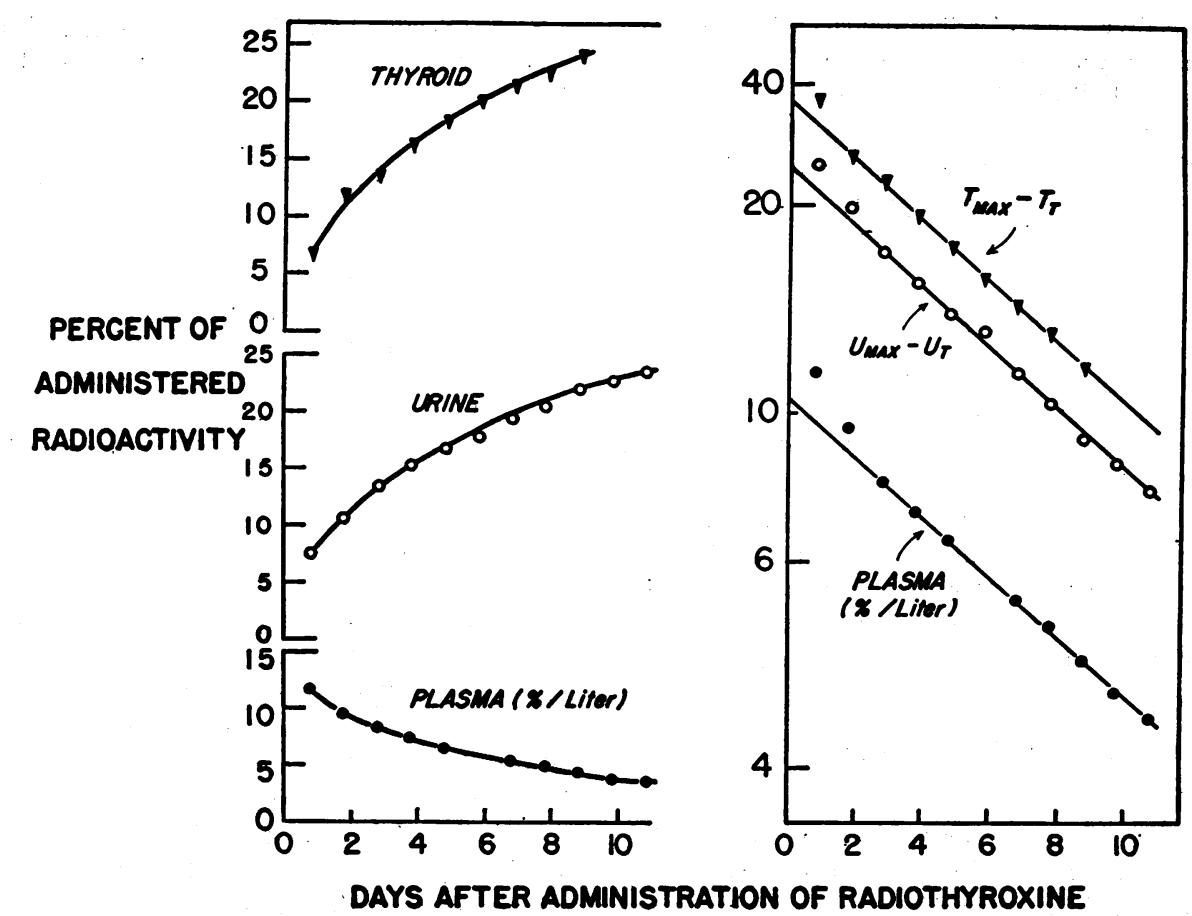

Fig. 2. Fate of Intravenously Administered Radiothyroxine in a Euthyroid Patient, Demonstrating that Radolodine Enters the Thyrom and Urine at the Same Rate at which Radiothyoxine Leaves the Plaska

per cent of the plasma's radioactivity was precipitable by trichloracetic acid. Thus, failure routinely to partition specimens of serum into organic and inorganic moieties could not have contributed an error greater than several per cent in the determination of TDS.

Since the rate of removal of iodide from the plasma exceeds greatly the rate of degradation of thyroxine, it was anticipated that, as Berson, Yalow, Schreiber, and Post have demonstrated for iodinated human serum albumin (14), the rate of entry of radioiodide into thyroid or urine would be governed by the rate of breakdown of administered $\mathrm{Tx}^{*}$. Both the urinary and thyroidal accumulation of radioiodine should therefore approach a maximum at the same exponential rate at which the concentration of $T x^{*}$ in plasma approaches a minimum (15). The daily increment in thyroidal and urinary radioiodine should diminish at the same exponential rate as does the concentration of $T x^{*}$ in plasma. This proved to be the case. It therefore became possible to calculate, from data collected over a 10 to 16-day period, theoretical values for the ultimate $(t=\infty)$ thyroidal and urinary accumulation of $I^{m}$.

If

$\mathrm{U}_{\mathrm{Max}}=$ Ultimate urinary collection of $\mathrm{I}^{\mathrm{m}}$ (Per cent administered dose).

$T_{\mathbf{x a x}_{\mathrm{ax}}}=$ Ultimate thyroidal collection of $\mathrm{I}^{\mathrm{m}}$ (Per cent administered dose).

$U_{t}=$ Urinary collection of $I^{m}$ at any time, $T$ (Per cent administered dose).
$T_{t}=$ Thyroidal collection of $I^{m 1}$ at any time, $t$ (administered dose).

Two points in time subsequent to completion of mixing of $\mathrm{Tx}_{\mathrm{x}}$ are chosen. As has been demonstrated following the administration of inorganic $I^{m}$ (15).

$$
\frac{U_{\text {Max }}-U_{1}}{U_{\text {Max }}-U_{2}}=\frac{P_{1}}{P_{2}}
$$

This equation may be solved for its one unknown, Unax. The values of $\left(U_{\max }-U_{1}\right)$ and $\left(U_{\max }-U_{2}\right)$, when plotted against time, define an exponential curve, parallel to the curve of the plasma's concentration of $\mathrm{Tx}^{*}$. Accuracy of collections, as well as calculation can be ascertained by plotting all observed values against this curve (Figure 2). The zero-time intercept of this curve should equal Une. However, since mixing of injected $T x^{*}$ is not instantaneous, metabolism of radiothyroxine and excretion of $\mathrm{I}^{12}$ may be excessive prior to the completion of mixing, when the concentration of $T x^{*}$ in plasma is inordinately great. The magnitude of this excessive or disproportionate loss of radioiodide into the urine will be reflected by the amount by which the zero-time intercept falls short of Unax.

Similar calculations can be made with values of thyroidal Im. Since the total dose of radioiodine eventually appears in thyroid, urine, or feces, it then becomes possible to calculate by the following formula a theoretical maximum fecal collection of $I^{131}$ ( $F_{\text {max }}$ ).

$$
F_{x a x}=100-\left(U_{\text {max }}+T_{x a x}\right) \text {. }
$$


TABLE I

Correlation between predicted and observed values of fecal excretion of $I^{131}$

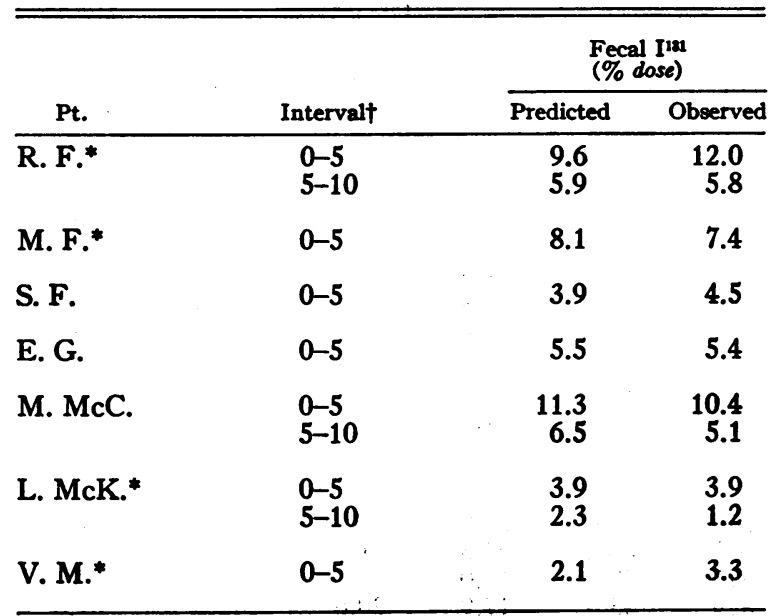

* Values obtained while patient receiving cortisone. Complete results will be presented in a subsequent publication.

$\dagger$ Days after administration of radiothyroxine.

It may be assumed that fecal collection of $I^{131}$ proceeds at the same exponential rate as loss of $T x^{*}$ from the plasma. This assumption is borne out by the data of Benua, Albert, and Keating (12). Cumulative fecal loss at any time $\left(F_{t}\right)$ may therefore be calculated according to the following formula.

$$
F_{t}=F_{\max }\left(1-e^{-\mathbf{z t}}\right) \text {. }
$$

The accuracy of determining fecal excretion of radioiodine in this indirect manner was checked in 10 instances (Table I). In no case did calculated and observed values differ by more than 2.4 per cent of the administered dose. Because of the difficulties inherent in accurately collecting and measuring radioactivity in daily fecal samples, the indirect method was utilized in subsequent patients.

Estimates of the mean daily production of thyroid hormone were made in the following manner. From each daily urinary collection, a standard percentage (1 per cent) was pooled with similar fractions from previous days. Analysis of the pooled urinary samples revealed the geometrical mean of the concentration of $I^{29}$ during the period of observation. The product of this value and the mean daily urinary volume revealed the average daily excretion of stable iodine. The increase in thyroidal and urinary collections of $I^{12 n}(\Delta T$ and $\Delta U$ ) between the completion of mixing of $\mathrm{Tx}^{*}$ and completion of the study was determined by inspection of appropriate accumulation curves. By the time mixing is complete negligible quantities of organic $I^{182}$ are present in the urine (11). It has further been demonstrated that following the administration of $T x^{*}$, the relative rates of entry of radioiodine into thyroid and urine are the same as those which follow the administration of inorganic $I^{m}$. These in turn may be considered to represent the relative rates of entry of inorganic $\mathrm{I}^{2 \pi}$ into these two sites (11, 12). Therefore,

$$
\frac{\Delta \mathrm{U}}{\Delta \mathrm{T}}=\frac{\text { daily urinary excretion of } \mathrm{I}^{127}}{\text { daily thyroidal accumulation of } \mathrm{I}^{127}} .
$$

This equation is then solved for its one unkown, the daily thyroidal accumulation of $\mathrm{I}^{\mathrm{IP}}$, or rate of production of hormone.

Observation of the urinary and thyroidal accumulation of $I^{121}$ following the administration of radiothyroxine also makes possible calculation of the fraction of liberated radioiodide which enters the thyroid gland. This has been designated the thyroidal fraction (T.F.).

$$
\text { T.F. (per cent) }=\frac{\Delta T \times 100}{\Delta T+\Delta U} \text {. }
$$

Since radioiodide liberated by the peripheral degradation of $\mathrm{Tx}^{*}$ apportions itself between thyroid and urine as does a tracer dose of inorganic radioiodide, the thyroidal fraction should be numerically equal to the ultimate thyroidal uptake of a tracer dose of inorganic $I^{\text {tan }}$. In 10 patients, values of the thyroidal fraction were compared with the uptake observed 48 hours after a usual tracer dose of radioiodide. In no instance did the thyroidal fraction differ from the observed uptake by more than $\mathbf{5 . 3}$ per cent of the administered dose; the mean difference between the two being 0.2 per cent uptake (Table II). The close agreement noted between predicted and observed values of the radioiodide uptake would appear to confirm both the accuracy of collections and measurements as well as the basic assumptions upon which the method depends.

\section{RESULTS}

Euthyroidism: (Table III.) The SPI in normal patients ranged from 3.0 to $7.0 \mu \mathrm{g}$. per cent. Thyroxine was found to be distributed in an average volume of $9.4 \mathrm{~L}$. and to be replaced at an average rate of 10.6 per cent per day. Mean vol-

TABLE II

Correlation between predicted and observed values of thyroidal fraction

\begin{tabular}{lcc}
\hline & \multicolumn{2}{c}{$\begin{array}{c}\text { Thyroidal fraction } \\
\text { (per cent) }\end{array}$} \\
\cline { 2 - 3 } Patient & Predicted & Observed \\
\hline M. B. & 29.5 & 24.2 \\
H. F. & 35.1 & 32.4 \\
B. H. & 29.0 & 30.0 \\
B. G. & 44.8 & 46.3 \\
V. M. & 40.1 & 43.5 \\
D. N. & 21.7 & 21.4 \\
R. N. & 22.7 & 21.7 \\
R. R. & 26.0 & 29.9 \\
R. R. & 22.1 & 24.5 \\
R. W. & 40.2 & 35.4 \\
Mean & 31.1 & 30.9 \\
\hline
\end{tabular}


TABLE III

Summary of values obtained in diverse states of thyroidal function*

\begin{tabular}{|c|c|c|c|c|c|c|c|c|c|c|c|}
\hline Pt. & Sex & $\underset{\text { (liters) }}{\operatorname{TDS}}$ & $(\% / d a y)$ & $(m l . / d a y)$ & $\begin{array}{c}\text { SPI } \\
\text { (us. I } \%)\end{array}$ & $\begin{array}{l}\text { ETT } \\
\text { M.I }\end{array}$ & (us. I/dey) & $\begin{array}{c}F_{\text {Max }} \\
(\% \text { dose })\end{array}$ & $\begin{array}{l}\mathrm{TF} \\
(\%) \\
\end{array}$ & $\begin{array}{c}\text { Urinary } \\
\text { iodine } \\
\text { (ab./dey) }\end{array}$ & $\begin{array}{c}\text { Hormone } \\
\text { product. } \\
\text { (ug.I/day) }\end{array}$ \\
\hline \multicolumn{12}{|c|}{ Myxedema, untreated } \\
\hline $\begin{array}{l}\text { P. C. } \\
\text { E. F. } \\
\text { F. G. } \\
\text { V. M. } \\
\text { L. McK. } \dagger\end{array}$ & $\begin{array}{l}\mathbf{M} \\
\mathbf{F} \\
\mathbf{F} \\
\mathbf{F}\end{array}$ & $\begin{array}{l}7.9 \\
8.0 \\
7.4 \\
6.6 \\
7.5\end{array}$ & $\begin{array}{r}9.77 \\
8.25 \\
10.34 \\
11.74 \\
8.89\end{array}$ & $\begin{array}{l}772 \\
660 \\
765 \\
763 \\
667\end{array}$ & $\begin{array}{l}1.1 \\
1.2 \\
1.3 \\
2.5 \\
1.2\end{array}$ & $\begin{array}{r}87 \\
96 \\
96 \\
165 \\
90\end{array}$ & $\begin{array}{r}8.5 \\
7.9 \\
9.9 \\
19.1 \\
8.0\end{array}$ & $\begin{array}{l}23.0 \\
11.6 \\
28.2 \\
22.5 \\
18.9\end{array}$ & $\begin{array}{c}0 \\
0 \\
0 \\
40.1 \\
0\end{array}$ & 79.3 & $\begin{array}{c}0 \\
0 \\
0 \\
53.1 \\
0\end{array}$ \\
\hline $\begin{array}{l}\text { Mean } \\
\text { Std. Dev. }\end{array}$ & & $\begin{array}{l}7.5 \\
0.6\end{array}$ & $\begin{array}{l}9.80 \\
1.36\end{array}$ & $\begin{array}{r}725 \\
57\end{array}$ & $\begin{array}{l}1.5 \\
0.6\end{array}$ & $\begin{array}{r}107 \\
33\end{array}$ & $\begin{array}{r}10.7 \\
4.8\end{array}$ & $\begin{array}{r}20.8 \\
7.1\end{array}$ & & & \\
\hline \multicolumn{12}{|c|}{ Myxedema, treated } \\
\hline $\begin{array}{l}\text { P. C. } \\
\text { M. F. } \\
\text { E. G. } \\
\text { V. M. } \\
\text { M. McC. } \\
\text { L. McK. } \\
\text { R. R. } \\
\text { G. S. } \\
\text { A. W. }\end{array}$ & $\begin{array}{l}\mathbf{M} \\
\mathbf{F} \\
\mathbf{F} \\
\mathbf{F} \\
\mathbf{F} \\
\mathbf{F} \\
\mathbf{M} \\
\mathbf{F} \\
\mathbf{F}\end{array}$ & $\begin{array}{r}7.9 \\
9.8 \\
11.7 \\
7.0 \\
8.1 \\
7.0 \\
9.4 \\
9.5 \\
9.2\end{array}$ & $\begin{array}{r}10.19 \\
9.76 \\
10.66 \\
10.83 \\
10.83 \\
9.76 \\
8.35 \\
9.00 \\
11.74\end{array}$ & $\begin{array}{r}805 \\
956 \\
1,247 \\
758 \\
878 \\
683 \\
785 \\
855 \\
1,080\end{array}$ & $\begin{array}{l}4.8 \\
6.3 \\
3.2 \\
4.7 \\
9.0 \\
6.0 \\
3.4 \\
4.4 \\
6.4\end{array}$ & $\begin{array}{l}379 \\
617 \\
375 \\
329 \\
729 \\
420 \\
320 \\
418 \\
589\end{array}$ & $\begin{array}{l}38.6 \\
60.2 \\
39.9 \\
35.6 \\
79.0 \\
41.0 \\
26.7 \\
37.6 \\
69.2\end{array}$ & $\begin{array}{l}25.9 \\
24.3 \\
13.0 \\
17.9 \\
27.0 \\
20.0 \\
24.7 \\
18.1 \\
15.9\end{array}$ & $\begin{array}{c}0 \\
0 \\
0 \\
20.6 \\
0 \\
0 \\
0 \\
0 \\
0\end{array}$ & $\begin{array}{l}145.5 \\
246.0\end{array}$ & $\begin{array}{c}0 \\
0 \\
0 \\
37.8 \\
0 \\
0 \\
0 \\
0 \\
0\end{array}$ \\
\hline $\begin{array}{l}\text { Mean } \\
\text { Std. Dev. }\end{array}$ & & $\begin{array}{l}8.8 \\
1.4\end{array}$ & $\begin{array}{r}10.12 \\
1.03\end{array}$ & $\begin{array}{l}894 \\
170\end{array}$ & $\begin{array}{l}5.4 \\
1.8\end{array}$ & $\begin{array}{l}464 \\
145\end{array}$ & $\begin{array}{l}47.5 \\
17.6\end{array}$ & $\begin{array}{r}20.8 \\
4.9\end{array}$ & & & \\
\hline \multicolumn{12}{|c|}{ Normal thyroidal function } \\
\hline $\begin{array}{l}\text { A. B. } \\
\text { R. C. } \\
\text { H. F. } \\
\text { B. G. } \\
\text { B. H. } \\
\text { D. M. } \\
\text { D. N. } \\
\text { R. N. } \\
\text { D. P. }\end{array}$ & $\begin{array}{l}M \\
M \\
F \\
F \\
F \\
M \\
F \\
M \\
M\end{array}$ & $\begin{array}{r}9.1 \\
10.4 \\
6.5 \\
7.7 \\
10.1 \\
9.5 \\
10.6 \\
8.0 \\
12.8\end{array}$ & $\begin{array}{r}8.88 \\
11.00 \\
10.50 \\
10.66 \\
9.49 \\
11.36 \\
10.83 \\
10.34 \\
11.95\end{array}$ & $\begin{array}{r}808 \\
1,144 \\
683 \\
821 \\
958 \\
1,079 \\
1,148 \\
827 \\
1,532\end{array}$ & $\begin{array}{l}5.1 \\
6.0 \\
7.0 \\
4.4 \\
7.0 \\
3.0 \\
5.5 \\
5.6 \\
5.2\end{array}$ & $\begin{array}{l}464 \\
624 \\
455 \\
339 \\
707 \\
285 \\
583 \\
448 \\
666\end{array}$ & $\begin{array}{l}41.2 \\
68.7 \\
47.8 \\
36.1 \\
67.1 \\
32.4 \\
63.2 \\
46.3 \\
79.6\end{array}$ & $\begin{array}{l}26.3 \\
33.2 \\
10.3 \\
33.8 \\
28.9 \\
15.2 \\
36.4 \\
36.1 \\
23.0\end{array}$ & $\begin{array}{l}37.1 \\
39.8 \\
35.1 \\
44.8 \\
29.0 \\
20.4 \\
21.7 \\
22.7 \\
31.1\end{array}$ & $\begin{array}{r}144.6 \\
107.2 \\
96.9 \\
50.9 \\
155.2 \\
130.5 \\
203.3 \\
142.5 \\
168.6\end{array}$ & $\begin{array}{l}85.4 \\
70.8 \\
52.4 \\
41.3 \\
63.4 \\
33.4 \\
56.4 \\
41.9 \\
76.0\end{array}$ \\
\hline $\begin{array}{l}\text { Mean } \\
\text { Std. Dev. }\end{array}$ & & $\begin{array}{l}9.4 \\
2.0\end{array}$ & $\begin{array}{r}10.56 \\
0.93\end{array}$ & $\begin{array}{r}1,000 \\
258\end{array}$ & $\begin{array}{l}5.4 \\
1.3\end{array}$ & $\begin{array}{l}508 \\
146\end{array}$ & $\begin{array}{l}53.6 \\
16.5\end{array}$ & $\begin{array}{r}26.9 \\
9.2\end{array}$ & $\begin{array}{r}31.3 \\
8.6\end{array}$ & $\begin{array}{r}133.3 \\
44.2\end{array}$ & $\begin{array}{l}57.9 \\
17.5\end{array}$ \\
\hline \multicolumn{12}{|c|}{ Hyperthyroidism } \\
\hline $\begin{array}{l}\text { A. B. } \\
\text { A. L. } \\
\text { D. L. } \\
\text { S. W. }\end{array}$ & $\begin{array}{l}\mathbf{F} \\
\mathbf{F} \\
\mathbf{M}\end{array}$ & $\begin{array}{r}8.1 \\
10.8 \\
4.7 \\
12.8\end{array}$ & $\begin{array}{l}21.66 \\
18.73 \\
31.50 \\
25.67\end{array}$ & $\begin{array}{l}1,754 \\
2,022 \\
1,480 \\
3,260\end{array}$ & $\begin{array}{l}17.0 \\
17.5 \\
14.6 \\
17.4\end{array}$ & $\begin{array}{r}1,377 \\
1,890 \\
686 \\
2,222\end{array}$ & $\begin{array}{l}297 \\
354 \\
216 \\
567\end{array}$ & $\begin{array}{l}18.0 \\
22.4 \\
35.9 \\
25.0\end{array}$ & $\begin{array}{l}91.6 \\
84.0 \\
81.4 \\
78.0\end{array}$ & $\begin{array}{l}101.0 \\
211.8 \\
121.0 \\
273.3\end{array}$ & $\begin{array}{r}1,101 \\
957 \\
530 \\
970\end{array}$ \\
\hline $\begin{array}{l}\text { Mean } \\
\text { Std. Dev. }\end{array}$ & & $\begin{array}{l}9.1 \\
3.5\end{array}$ & $\begin{array}{r}24.39 \\
5.53\end{array}$ & $\begin{array}{r}2,129 \\
770\end{array}$ & $\begin{array}{r}16.6 \\
1.4\end{array}$ & $\begin{array}{r}1,544 \\
670\end{array}$ & $\begin{array}{l}359 \\
150\end{array}$ & $\begin{array}{r}25.3 \\
7.6\end{array}$ & $\begin{array}{r}83.8 \\
5.8\end{array}$ & $\begin{array}{r}176.8 \\
80.4\end{array}$ & $\begin{array}{l}890 \\
248\end{array}$ \\
\hline M. T. $\ddagger$ & $\mathbf{M}$ & 6.9 & 16.12 & 1,112 & 9.0 & 621 & 100 & 16.8 & 0 & & 0 \\
\hline \multicolumn{12}{|c|}{ Panhypopituitarism } \\
\hline $\begin{array}{l}\text { M. B. } \\
\text { E. D. } \\
\text { R. R. } \dagger\end{array}$ & $\begin{array}{l}\mathbf{F} \\
\mathbf{F}\end{array}$ & $\begin{array}{r}11.6 \\
7.5 \\
8.6\end{array}$ & $\begin{array}{l}7.14 \\
8.66 \\
7.53\end{array}$ & $\begin{array}{l}828 \\
650 \\
648\end{array}$ & $\begin{array}{l}3.0 \\
2.6 \\
1.9\end{array}$ & $\begin{array}{l}348 \\
195 \\
163\end{array}$ & $\begin{array}{l}24.7 \\
16.9 \\
12.3\end{array}$ & $\begin{array}{l}31.2 \\
17.8 \\
19.4\end{array}$ & $\begin{array}{l}29.5 \\
16.0 \\
26.0\end{array}$ & $\begin{array}{r}71.2 \\
110.0 \\
43.3\end{array}$ & $\begin{array}{l}29.8 \\
21.0 \\
16.1\end{array}$ \\
\hline Mean & & 9.2 & 7.78 & 709 & 2.5 & 235 & 18.0 & 22.8 & 20.5 & 74.8 & 22.3 \\
\hline
\end{tabular}

* See text for explanation of symbols.

† Studied again after therapy with desiccated thyroid. value.

$\ddagger$ Patient received $300 \mathrm{mg}$. propylthiouracil and 30 qts. Lugol's solution daily during study. SPI is pre-treatment 
ume turnover was $1000 \mathrm{ml}$. per day. The normal extrathyroidal content of thyroxine averaged $508 \mu \mathrm{g}$. hormonal iodine and $53.6 \mu \mathrm{g}$. of hormonal iodine were utilized per day.

Treated myxedema: All patients were judged to be euthyroid on the basis of clinical picture and BMR. SPI in this group ranged between 3.2 and $9.0 \mu \mathrm{g}$. per cent. Values for all functions agreed well with those of the euthyroid group.

Primary myxedema: In the five subjects comprising this category, SPI ranged from 1.1 to 2.5 $\mu \mathrm{g}$. per cent. A significant reduction of the TDS was observed (mean, $7.5 \mathrm{~L} . ; \mathrm{p}<.02$ ). Although the fractional rate of turnover of thyroxine was somewhat less than normal, a statistically significant reduction could not be demonstrated. As a result of the diminution in these functions, the average daily volume turnover of the thyroxine space was significantly reduced (mean, $725 \mathrm{ml}$; $\mathrm{p}<.01)$. Similarly total extrathyroidal thyroxine (mean, $10.7 \mu \mathrm{g} . \mathrm{I} ; \mathrm{p}<.01$ ) and the daily rate of utilization of thyroxine (mean, $10.7 \mu \mathrm{g} I$ per day; $p<.01$ ) were significantly less than normal.

Panhypopituitarism: Because of the small number of patients available for study, statistical analysis of results in this group was not carried out. The distribution and rate of turnover of thyroxine appeared to be similar to that observed in patients with untreated myxedema, but SPI was uniformly greater, and consequently, utilization of hormone, although subnormal, was considerably more than that encountered in the myxedematous group.

Hyperthyroidism: Studies were performed in four patients with untreated hyperthyroidism whose SPI's ranged from 14.6 to $17.5 \mu \mathrm{g}$. per cent. For the following reasons, other results in this group must be considered approximations of those which truly pertain. Radioiodine liberated by the peripheral degradation of thyroxine is apportioned between the thyroid and the urine. In patients with thyrotoxicosis, the larger fraction of this inorganic radioiodide enters the thyroid gland. Once incorporated into hormone, the radioiodine is rapidly released into the circulation $(1,16)$. The accelerated turnover of radioiodine in the thyrotoxic gland results in a progressive underestimation of the thyroidal accumulation of $\mathrm{I}^{131}$ and in a restoration to the thyroxine space of a portion of the radiothyroxine initially injected. Thus, there results an overestimation of the plasma's concentration of exogenously administered $\mathrm{Tx}^{*}$ and an underestimation of the rapidity of its degradation. Finally, as the endogenously synthesized radiothyroxine is degraded, a fraction of the radioiodide thereby liberated will also enter the urine and hence will augment the urinary radioactivity resulting from the initial cycling of $\mathrm{Tx}^{*}$.

That this sequence of events did transpire in patients with untreated thyrotoxicosis is suggested by the following observations. In contrast to the findings of patients in other clinical categories, in whom a continuously increasing thyroidal content of $\mathrm{I}^{131}$ was noted, thyroidal radioactivity increased during the first several days after administration of $T x^{*}$, and then either decreased or remained constant. Similar curves of the thyroidal accumulation of $\mathrm{I}^{131}$ following the administration of $\mathrm{Tx}^{*}$ to hyperthyroid patients have been noted by Benua, Albert, and Keating (12). When the daily increment in thyroidal $\mathrm{I}^{131}$ during the first several days was plotted, an exponential curve with a slope parallel to that of the plasma's concentration of $\mathrm{Tx}^{*}$ was defined. Subsequent points, however, fell progressively below a projection of the initial slope.

It is well known that radioactive hormone may be released from the thyroid gland within a few hours after the initial penetration of inorganic $\mathrm{I}^{131}$ (17). However, in the present system, the earliest gross manifestation of hormonal release was the appearance of a deficit in the thyroidal increment of radioiodine, as noted above. This was mirrored in the urine by an excessively large daily increment in $\mathrm{I}^{131}$ and in the plasma by a retardation of the rate of disappearance of radiothyroxine.

If endogenously synthesized radiothyroxine were instantaneously mixed throughout its distribution compartment, these events would not alter values of TDS obtained by the present method, which relates the amount of $\mathrm{Tx}^{*}$ within the thyroxine space to its concentration therein. Only the observed fractional rate of turnover would be affected (decreased). However, mixing of thyroxine is not instantaneous. As a consequence, the magnitude and direction of errors in the estimation of the thyroxine space will depend upon two factors: a) The relative rapidities of hormonal turnover within the gland and hormonal mixing within the thyroxine space, and b) alterations in fecal losses resulting from retardation of 
the net disappearance of thyroxine from the plasma.

Despite the foregoing difficulties, an attempt was made to derive approximate values in hyperthyroid patients by the method described. Calculations were based on data obtained only during the interval between the completion of mixing of administered radiothyroxine (i.e., subsequent to 24 hours) and the first gross manifestation of release of radioactive hormone from the thyroid gland ( 72 to 120 hours).

The mean TDS of hyperthyroid patients did not appear to differ significantly from the normal value. The fractional rate of turnover was, however, markedly augmented (mean, 24.39 per cent per day; $\mathrm{p}<.01$ ) as was daily volume turnover (mean 2,129 ml. per day ; $\mathrm{p}<.02$ ). SPI ranged from 14.6 to $17.5 \mu \mathrm{g}$. per cent. Total extrathyroidal thyroxine (mean, $1544 \mu \mathrm{g}$. I; $\mathrm{p}<.05$ ) and daily rate of utilization of thyroxine (mean, $359 \mu \mathrm{g} . \mathrm{I} ; \mathrm{p}<.01$ ) were significantly greater than normal.

Since only early data were used in these calculations, it remained possible that the apparently rapid turnover rate might in part represent continued mixing of injected $\mathrm{Tx}^{*}$. Therefore, one untreated patient (M. T.) with thyrotoxicosis was given $300 \mathrm{mg}$. of propylthiouracil and 30 drops of Lugol's solution daily during the determination of his rate of degradation of thyroxine. ${ }^{7}$ This medication completely inhibited the thyroidal accumulation of radioiodine, and thereby prevented the recycling of radiothyroxine. Despite the fact that the patient experienced rapid and nearly complete symptomatic response during the period of observation, the fractional rate of turnover of thyroxine was more rapid than that noted in any non-hyperthyroid patient, and fell near the range noted in other hyperthyroid patients who received no antithyroid therapy.

Production of thyroid hormone: Daily incorporation of $\mathrm{I}^{127}$ into the thyroid gland averaged $57.9 \mu \mathrm{g}$. iodine in euthyroid subjects and $890 \mu \mathrm{g}$. iodine in patients with untreated thyrotoxicosis. Patients with pituitary myxedema displayed a rate of hormonal production averaging $22.3 \mu \mathrm{g}$. iodine per day. Except in the case of patient V. M., thy-

\footnotetext{
7 Preliminary studies, employing patients with primary myxedema, indicate that iodides do not alter the rate of utilization of radioactive thyroxine.
}

roidal accumulation of radioiodine and consequently measurable thyroidal production of hormone could not be demonstrated in patients with primary myxedema. Patient V. M. has for years displayed classical signs and symptoms of hypothyroidism, together with abnormally low BMR and SPI, despite 24-hour thyroidal uptakes of I31 ranging from 40 to 50 per cent. The present studies revealed a normal rate of production of hormone, an abnormally low rate of degradation of thyroxine, and a diminished SPI. Preliminary studies in this patient suggest that her thyroid gland is producing and releasing into the circulation both thyroxine and a calorigenically less potent iodinated derivative whose solubility characteristics differ from those of thyroxine.

Relation between production of thyroid hormone and degradation of thyroxine: In individual patients with normal thyroidal function or panhypopituitarism, concomitantly measured rates of production of thyroid hormone and degradation of thyroxine were closely correlated $(r=0.84 \pm$ $0.19, \mathrm{p}=.002$ ). Analysis by the "paired t" test revealed no significant difference between paired values in individual patients $(p>0.2)$. In only one patient, A. B., a 45-year old alcoholic man with slowly resolving pneumonia, did paired values differ markedly. Although several patients in the normal group had recently been ill, A. B. was the only patient who had not convalesced completely at the time of study.

In thyrotoxic patients, calculated values for the daily production of hormone averaged $890 \mu \mathrm{g}$. and consistently exceeded estimates of the daily degradation of thyroxine.

\section{DISCUSSION}

Disappearance of hormone may reflect either a) utilization specifically associated with its action on an end organ, or b) degradation which is not linked to the mechanism of hormonal action. Since no known method will differentiate between these possibilities with regard to thyroid hormone, solely the term degradation is used herein to denote overall disappearance of thyroxine from its compartment of distribution.

Several previous studies of the degradation of radioactive thyroxine have employed conventional extrapolation techniques $(3,18-20)$. Potential errors of this technique are well known, and may 
influence both the measured space and the turnover rate $(14,21)$. These errors arise as a result of disproportionate metabolism of the labelled metabolite during the mixing period, failure to observe the plasma's slope for a sufficiently long period, and nonhomogeneity of the injected material.

The present method seeks to avoid these errors. The virtual volume of distribution of thyroxine at any time may be calculated as the quotient of the $\mathrm{Tx}^{*}$ remaining in the space and its concentration therein. Rapidly metabolized contaminants, once cleared from the space, do not therefore influence the results. Constancy of calculated volumes of distribution indicates that mixing has been completed, and that the fractional rate of degradation may then be determined from the subsequent slope of the curve depicting the concentration of $\mathrm{Tx}^{*}$ in the plasma.

By means of the present technique, the mean normal rate of degradation of thyroxine was found to be $53.6 \mu \mathrm{g}$. thyroxine iodine per day in normal subjects and $47.5 \mu \mathrm{g}$. thyroxine iodine per day in euthyroid patients with treated myxedema. These values agree with estimates of the daily requirement for hormone which others have derived, using a variety of methods $(4,20,22)$.

As might be anticipated, breakdown of thyroxine was considerably increased in thyrotoxic subjects and profoundly diminished in patients with untreated myxedema. Values intermediate between those obtained in the euthyroid and the myxedematous groups were derived in patients with panhypopituitarism.

An examination of the constituent functions reveals the sources of differences in degradation of thyroxine noted. In normal patients thyroxine distributed in a volume of approximately $9.4 \mathrm{~L}$. Approximately 10 per cent of the thyroxine contained within the space was replaced by newly released hormone each day. The thyroxine contained within approximately $1,000 \mathrm{ml}$. of the space was renewed each day. In myxedematous patients, the volume of the TDS was significantly diminished, and the fractional rate of turnover of Tx* was slightly reduced. As noted above, results in patients with hyperthyroidism must be interpreted with some reservations. Nevertheless, the TDS did not appear to differ from normal in patients with this disease.
Daily volume turnover of thyroxine did not differ significantly among patients with normal thyroidal function, treated myxedema, and panhypopituitarism. In patients with untreated myxedema, this function was reduced by about 25 per cent. Nevertheless, the large differences between the rates of degradation among these non-thyrotoxic groups were largely conditioned by and proportional to differences in the SPI. In the thyrotoxic patients, degradation was not proportional solely to the SPI, since the fractional turnover rate and therefore the daily volume turnover were markedly augmented (Figure 3). Proportional utilization of thyroxine, together with moderate reduction in the daily volume turnover of myxedematous patients may explain the relative ease with which the SPI can be elevated by standard doses of desiccated thyroid when the SPI is low, compared with the relative difficulty encountered in augmenting SPI when its concentration is normal or increased (23). Furthermore, it may be surmised that the disproportionately rapid degradation of thyroxine in the hyperthyroid patient, resulting from an increased fractional rate of turnover, would tend to lower the SPI and to make this measurement a rather insensitive index of the quantity of hormone used. It may further be noted that the relationship between SPI and degradation of thyroxine depicted in Figure 3 closely approximates the relationship between SPI and hormonal production and degradation, described by Burrows and Ross (24) and by Berson and Yalow (4), respectively.

Several further inferences concerning the metabolism of thyroxine may be drawn from the foregoing data. When administered to rats, large doses of thyroxine labelled with $\mathrm{I}^{131}$ are more rapidly metabolized than are small doses $(25,26)$. An analogy may therefore be sought in the rapid disappearance of thyroxine from the plasma of thyrotoxic patients. The more rapid removal of thyroxine under these circumstances could be ascribed to detoxification, perhaps performed by the liver (26-28). Although the present method does not ascertain the ultimate metabolic fate of thyroxine, it does permit evaluation of the relative quantity of hormonal iodine which is reduced to inorganic iodine and that which is excreted in the organic form via the feces. Normally approximately 25 per cent of $\mathrm{I}^{131}$ administered as $\mathrm{Tx}^{*}$ 


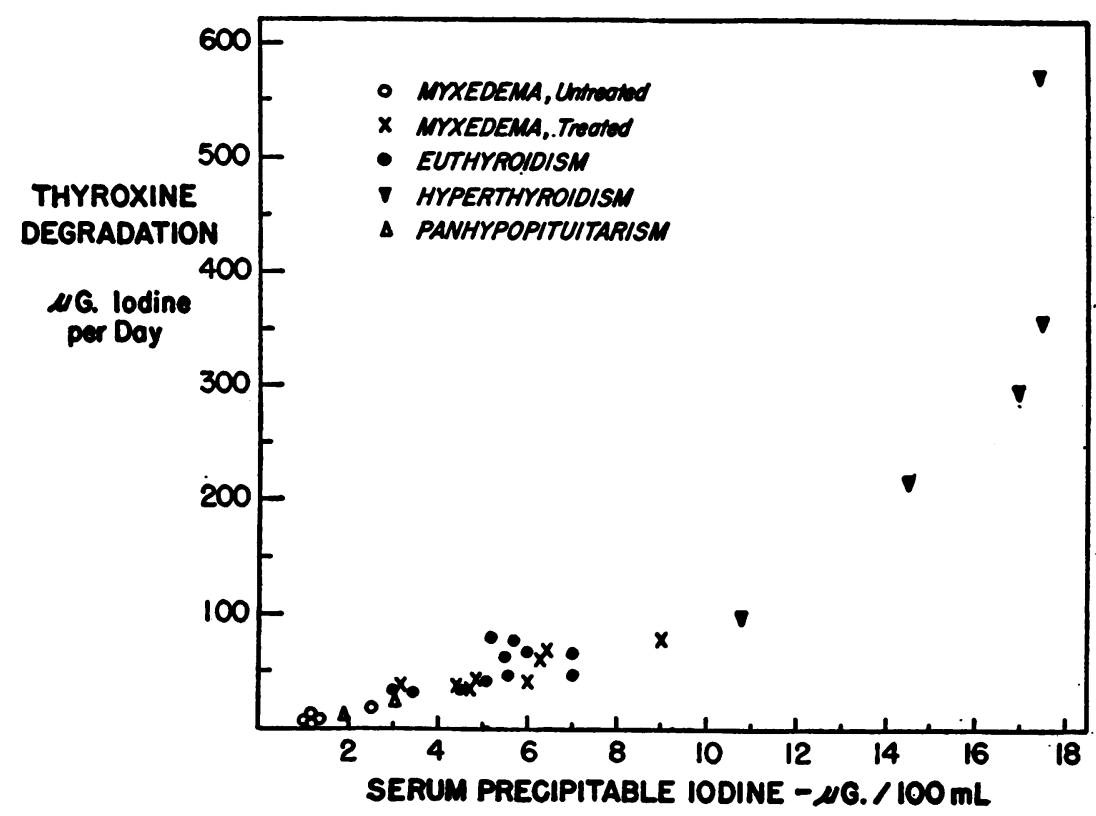

Fig. 3. Relation between the Circulating Concentration and Rate of Degradation of Thyrom Hormone

The relationship illustrated probably represents a continuous curved function. However, in the non-thyrotoxic range, the relationship approaches linearity.

appears in the feces, the remainder entering the thyroid or urine. In the hyperthyroid patient given radiothyroxine, this apportionment between fecal and non-fecal moieties did not differ significantly from the normal.

It has recently been suggested that augmented salivary deiodination of compounds containing organically bound iodine may occur in myxedema, and that salivary deiodination mechanisms, perhaps under hypophyseal control, may serve to maintain the balance of thyroid hormone in the body (29-31). There is ample evidence which the present study supplements, that thyroxine is the principle iodinated compound released by the thyroid gland. A predicated enhancement of deiodination in patients with myxedema is clearly not consistent with the observation that the fractional rate of turnover of thyroxine in such patients is, if anything, slower than that found in patients with normal thyroidal function or with treated myxedema.

The precise anatomical limits of the thyroxine space obviously cannot be defined. However, the values noted above for the distribution and rate of turnover of thyroxine are similar in magnitude to those previously reported for certain of the pro- teins in plasma $(14,32-34)$. In plasma, thyroxine is bound to an $\alpha$-globulin (35-37). One may wonder whether the distribution and fate of thyroxine are related to the fate of the protein to which it is bound. The reduction in TDS in patients with untreated myxedema might there be analogous to the reduction in myxedema of the volume of dilution of dyes whose distribution is limited by their protein carrier (38). Similarly, alteration in the rate of turnover of thyroxine in patients with myxedema or thyrotoxicosis would then be consistent with parallel alterations in the rate of turnover of protein and other metabolites in these diseases (39-41). Studies designed to evaluate this hypothesis are in progress. However, preliminary observations suggest that the abnormally rapid removal of thyroxine seen in hyperthyroid patients may persist for months following the complete amelioration of the thyrotoxic state (7). The relationship of this metabolic abnormality to the inception or continuance of the disease state obviously remains to be clarified.

Although the present data do not make possible an appraisal of the metabolic fate and calorigenic importance of all iodinated compounds contained in thyroid extract, it was possible to demonstrate 
TABLE IV

Relationship between degradation of thyroxine and dose of U.S.P. thyroid extract in patients with primary myxedema

\begin{tabular}{|c|c|c|c|}
\hline Pt. & Mg. I/dey & $\begin{array}{c}\text { Thyroid } \\
\text { doee } \\
\text { er./dey }\end{array}$ & $\begin{array}{c}\text { Ratio } \\
\text { Me. I/gr. }\end{array}$ \\
\hline \multirow[t]{2}{*}{$\begin{array}{l}\text { G. S. } \\
\text { P. C. } \\
\text { E. G. } \\
\text { L. M. } \\
\text { M. F. } \\
\text { A. W. }\end{array}$} & $\begin{array}{l}37.6 \\
38.6 \\
39.9 \\
41.0 \\
60.2 \\
69.2\end{array}$ & $\begin{array}{l}1.5 \\
2.0 \\
2.0 \\
2.0 \\
3.0 \\
3.5\end{array}$ & $\begin{array}{l}25.1 \\
19.3 \\
20.0 \\
20.5 \\
20.1 \\
19.8\end{array}$ \\
\hline & & & $20.8 \pm 2.1$ \\
\hline
\end{tabular}

* Thyroxine degradation.

virtual equivalence between intake of exogenous thyroxine and degradation of this hormone. In six athyreotic patients under therapy with thyroid extract, an average of $21.0 \mu \mathrm{g}$. thyroxine iodine was degraded per grain of U.S.P. thyroid extract administered (Table IV). Since this preparation contains an average of $120 \mu \mathrm{g}$. total iodine, of which approximately 25 per cent is in the form of thyroxine (42), roughly 70 per cent of thyroxine apparently is absorbed. Of further interest was the observation that in the one myxedematous patient (V. M.) in whom measurable intrathyroidal iodinations were proceeding, daily administration of one grain of thyroid extract diminished this process by $15.3 \mu \mathrm{g}$. per day.

The present method does not necessitate inhibition of thyroidal accumulation of radioiodide liberated by the peripheral degradation of $\mathrm{Tx}^{*}$, and thus makes possible estimation of the relative rates of entry of inorganic iodide into thyroid and urine. Hence, measurements of the daily excretion of stable iodine may be used to calculate the daily thyroidal accumulation of $\mathrm{I}^{122}$, or rate of production of hormone. In individual non-thyrotoxic subjects, close agreement has been noted between the daily incorporation of $\mathrm{I}^{127}$ into organic moieties and the concomitantly measured daily degradation of thyroxine (Figure 4).

Production and utilization of hormone in patients with panhypopituitarism although less than normal, exceeded considerably that found in patients with primary myxedema. The present data, which are apparently the first measurements of absolute rates of production of thyroid hormone in patients with pituitary myxedema, substantiate the lesser severity of myxedema arising from pituitary rather than from thyroidal failure.

In patients with hyperthyroidism, calculated values for the rate of production of thyroid hormone markedly exceeded values of the rate of degradation of thyroxine. This discrepancy could result from several factors. First, disparate values might represent a methodological artifact. Since, in thyrotoxic patients, the rapid turnover of iodine results in a diminution in the apparent thyroidal accumulation and an increase in the urinary excretion of $\mathrm{I}^{131}$, it might be anticipated that rates of production of hormone would be underestimated. However, it is likely that rates of degradation are also underestimated. As noted earlier, release of radioactive hormone from the hyperfunctioning thyroid gland is rapid, and significant quantities of newly synthesized radiothyroxine may certainly have entered the circulation by the time mixing of exogenous $\mathrm{Tx}^{*}$ was complete. It is likely that even the early slopes of disappearance of $\mathrm{Tx}^{*}$ from plasma were slowed, and rates of degradation therefore underestimated. The relative magnitudes of these errors in the estimation of production and degradation cannot be assessed.

Alternatively, the observations may reflect a true disparity. Repletion of glandular stores of stable iodine during the period of observation (10 to 16 days) might be one of the means whereby thyroidal incorporation of iodine could exceed

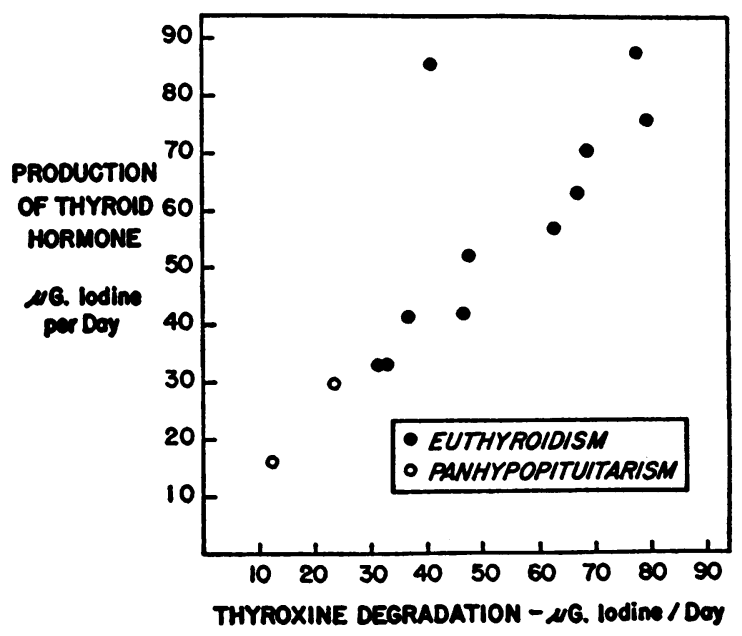

Fic. 4. Relation between Rates of Production of Thyrom Hormone and Degradation of Thyroxine in Non-Thyrotoxic Patients 
the peripheral degradation of thyroxine. Similarly, release from the gland of quantities of thyroxine in excess of those being removed from the circulation could also be invoked. Although values of the SPI remained constant during the period of study, more prolonged observation might have revealed an increase in the concentration of circulating hormone. Another possible mechanism would be the synthesis and release of iodinated compounds other than thyroxine. Such compounds, e.g., triiodothyronine, which are widely distributed and rapidly metabolized (18, 20), would be expected to contribute but little to circulating protein-bound iodine. Unfortunately, available data does not permit differentiation between these or other alternatives.

The present data demonstrate for the first time a close correlation between the rate of degradation of thyroxine and the rate of incorporation of iodine by the thyroid gland of the non-thyrotoxic patient. If, on the one hand, thyroxine is the principal iodinated compound produced and released by the thyroid gland, it may be concluded that mean glandular content of iodine remains constant over a period of 10 to 16 days. On the other hand, if it be assumed that glandular thyroxine remains constant, then thyroxine must constitute the principal end-product of thyroidal organic iodinations. One cannot logically conclude that either premise is necessarily true. However, their equivalence has been demonstrated by the present findings, and hence validation of both premises requires merely the verification of one.

\section{SUMMARY}

1. A method has been described which makes possible the simultaneous estimation of the rate of degradation of thyroxine and the rate of synthesis of thyroid hormone.

2. In non-thyrotoxic patients, a close agreement between values of these functions has been noted.

3. Factors influencing the distribution and fate of thyroxine in diverse states of thyroidal function have been evaluated.

\section{ACKNOWLEDGMENTS}

The authors are indebted to Miss Barbara Fine and Miss Mary Frances Chapin for invaluable technical assistance.

\section{REFERENCES}

1. Riggs, D. S, Quantitative aspects of iodine metabolism in man. Pharmacol. Rev., 1952, 4, 284.

2. Ingbar, S. H., Kleeman, C. R., Quinn, M., and Bass, D. E., The effect of prolonged exposure to cold on thyroidal function in man. Clin. Res. Proc., $1954,2,86$.

3. Meszaros, J., and Robbins, $\ddot{\boldsymbol{R}}$, Kinetics of proteinbound iodine release and utilization. Clin. Res. Proc., 1954, 2, 85.

4. Berson, S. A.; and Yalow, R. S., Quantitative aspects of iodine metabolism. The exchangeable organic iodine pool, and the rates of thyroidal secretion, peripheral degradation and fecal excretion of endogenously synthesized organically bound iodine. J. Clin. Invest., 1954, 33, 1533.

5. Gutman, A. B., Benedict, E. M., Baxter, B., and Palmer, W. W., The effect of administration of iodine on the total iodine, inorganic iodine, and thyroxine content of the pathological thyroid gland. J. Biol. Chem., 1932, 97, 303.

6. Ingbar, S. H., Freinkel, N., Hoeprich, P. D., and Athens, J. W., The concentration and significance of the butanol-extractable $I^{m}$ of serum in patients with diverse states of thyroidal function. J. Clin. Invest., 1954, 33, 388.

7. Ingbar, S. H., and Freinkel, N., Unpublished observations.

8. Barker, S. B., Humphrey, M. J., and Soley, M. H., The clinical determination of protein-bound iodine. J. Clin. Invest., 1951, 30, 55.

9. Barker, S. B., Determination of protein-bound iodine. J. Biol. Chem., 1948, 173, 715.

10. Snedecor, G. W., Statistical Methods Applied to Experiments in Agriculture and Biology. 4th ed., Ames, The Iowa State College Press, 1946.

11. Myant, N. B., and Pochin, E. E., The metabolism of radiothyroxine in man. Clin. Sc., 1950, 9, 421.

12. Benua, R. S., Albert, A., and Keating, F. R., Jr., The metabolism of radiothyroxine in exophthalmic goiter. J. Clin. Endocrinol. \& Metab., 1952, 12, 1461.

13. Albert, A., and Keating, F. R., Jr., Metabolic studies with $I^{m 1}$ labeled thyroid compounds. Comparison of the distribution and fate of radioactive d-1-thyroxine after oral and intravenous administration in the human. J. Clin. Endocrinol., 1949, 9, 1406.

14. Berson, S. A., Yalow, R. S., Schreiber, S. S., and Post, J., Tracer experiments . with $I^{110}$ labeled human serum albumin: distribution and degradation studies. J. Clin. Invest., 1953, 32, 746.

15. Ingbar, S. H., Simultaneous measurement of the iodide-concentrating and protein-binding capacity of the human thyroid gland. J. Clin. Endocrinol. \& Metab., 1955, 15, 238.

16. Freedberg, A. S., Chamovitz, D. L., and Kurland, G. S., Thyroid function in normal and pathological states as revealed by radioactive iodine studies. 
I. Thyroid In uptake and turnover in euthyroid, hyperthyroid, and hypothyroid subjeets. Metabolism, 1952, 1, 26.

17. McConahey, W. M., Keating; F: R., Jr.i and Power, M. H., The behavior of radioiodine in the blopd. J. Clin. Invest., 1949, 28, 191.

18. Rawson, R. W. Rall; J. E., Pearson, O: Hi., Robbins, J., Poppell, H. F., and West, C. D., L-trifodothyiro nine versus 1-thyroxine, a comparison of their metabolic effects in human myxedema. Am. J. M. Sc., 1953, 226, 405.

19. Hamolsky, M.: W., Freedberg, A. S., Kurland, G. S., and Wolsky, L., The exchangeable thyroid hormonal pool. I. Its magnitude and rate of turnover in various thyroid states in man. $\mathrm{J}$. Clin. Invest., 1953, 32, 453.

20. Sterling, K., Lashof, J. C., and Man, E. B., Disappearance from serum of $I^{12 x}$-labeled 1-thyroxine and 1-triiodothyronine in euthyroid subjects. $\mathrm{J}$. Clin. Invest., 1954, 33, 1031.

21. Freinkel, N., Schreiner, G. E., and Athens, J. W., Simultaneous distribution of T-1824 and Im-labelled human serum albumin in man. $\mathrm{J}$. Clin. Invest., 1953, 32, 138.

22. Stanbury, J. B., Brownell, G. L., Riggs, D. S., Perinetti, H., del Castillo, E., and Itoiz, J., The iodinedeficient human thyroid gland. A preliminary report. J. Clin. Endocrinol. \& Metab., 1952, 12, 191.

23. Greer, M. A., and Smith, G. E., Method for increasing the accuracy of the radioiodine uptake as a test for thyroid function by the use of desiccated thyroid. J. Clin. Endocrinol. \& Metab., 1954, 14, 1374.

24. Burrows, B. A., and Ross, J. F., The thyroidal uptake of stable iodine compared with the serum concentration of protein-bound iodine in normal subjects and in patients with thyroid disease. J. Clin. Endocrinol. \& Metab., 1953, 13, 1358.

25. Gross, J., and LeBlond, C. P., Metabolism of the thyroid hormone in the rat as shown by physiological doses of labeled thyroxine. J. Biol. Chem., 1950, $184,489$.

26. Taurog, A., Briggs, F. N., and Chaikoff, I. L., I ${ }^{12}$ labeled 1-thyroxine. I. An unidentified excretion product in bile. J. Biol. Chem., 1951, 191, 29.

27. Albert, A., and Keating, F. R., Jr., The role of the gastrointestinal tract, including the liver, in the metabolism of radiothyroxine. Endocrinology, 1952, 51, 427.

28. Albert, A., Ford, E., and Lorenz, N., Effects of altered thyroid function upon the metabolism of endogenously labeled thyroid hormone. Endocrinology, 1953, 53, 50 .
29. Fawicett, D. M., and Kirkwood, S., Tyrosine iodinase. J. Biol. Chem., 1954, 209, 249.

30. Thode, H. G., Jaimet, C. H., and Kirkwood, S., Studies and diagnostic tests of salivary-gland and thyroid-gland function with radioiodine. New England J. Med., 1954, 251, 129.

31. Fawcett; D. M.; and Kirkwood; S., Role of the salivary glands in extrathyroidal iodine metabolism. Science, 1954, 120, 547.

32. Sterling, $\boldsymbol{K}$, Serum albumin turnover in Laennec's cirrhosis as measured by $\mathrm{I}^{\mathrm{mm}}$-tagged albumin. $\mathrm{J}$. Clin. Invest., 1951, 30, 1238

33. Myant, N. B., Observations on the metabolism of human gamma globulin labelled by radioactive iodine. Clin. Sc., 1952, 11, 191.

34. Vaughan, J. H., Armato, A., Goldthwaite, J., Brachman, P., Favour, C. B., and Bayles, T. B., Fate of intravenously injected labelled gamma globulin in the normal subject and in patients with rheumatoid arthritis. J. Clin. Invest., 1952, 31, 668.

35. Gordon, A. H., Gross, J., O'Connor, D., and PittRivers, R., Nature of the circulating thyroid hormone-plasma protein complex. Nature, 1952, 169, 19.

36. Deiss, W. P., Albright, E. C., and Larson, F. C., A study of the nature of the circulating thyroid hormone in euthyroid and hyperthyroid subjects by use of paper electrophoresis. J. Clin. Invest., 1952, 31, 1000 .

37. Robbins, J., and Rall, J. E, Zone electrophoresis in filter paper of serum $I^{13}$ after radioiodide administration. Proc. Soc. Exper. Biol. \& Med., 1952, 81, 530.

38. Thompson, W. O., Studies in blood volume. I. The blood volume in myxedema, with a comparison of plasma volume changes in myxedema and cardiac edema. J. Clin. Invest., 1926, 2, 477.

39. Rosenman, R. H., Byers, S. O., and Friedman, M., The mechanism responsible for altered blood cholesterol content in deranged thyroid states. J. Clin. Endocrinol. \& Metab., 1952, 12, 1287.

40. Hoberman, H. D., Endocrine regulation of amino acid and protein metabolism during fasting. Yale J. Biol. \& Med., 1950, 22, 341.

41. Crispell, K. R., Parson, W., and Hollifield, G. F., The amino acid pool and the protein synthesis rate in patients with primary myxedema before and after treatment with 1-triiodothyronine. Clin. Res. Proc., 1954, 2, 86 .

42. Palmer, W. W., and Leland, J. P., Comparative calorigenic action of normal and pathological thyroid glands administered in equi-thyroxine doses. J. Clin. Invest., 1935, 14, 619. 